Огляди літератури, оригінальні дослідження, погляд на проблему, випадок з практики, короткі повідомлення УДК 616.89::616.895+616.891:616-057

DOI 10.11603/1811-2471.2020.v.i1.11076

\title{
АНАЛІЗ АДИКТИВНИХ ФЕНОМЕНІВ У ПРЕДСТАВНИКІВ КОМАНДНОГО СКЛАДУ МОРСЬКОГО ТОРГОВЕЛЬНОГО І ПАСАЖИРСЬКОГО ФЛОТІВ
}

\author{
ОК. А. Косенко ${ }^{1,2}$, К. Д. Гапонов² \\ ${ }^{1}$ КНП «Одеський обласний медичний центр психічного здоров'я» Одеської обласної ради \\ ${ }^{2}$ Харківська медична академія післядипломної освіти
}

\begin{abstract}
РЕЗЮМЕ. Мета роботи - дослідити напруженість адиктивного статусу (АС) у представників командного складу морського торговельного і пасажирського флотів з різним рівнем психосоціального стресу (ПС) для визначення необхідності створення специфічних для даного контингенту системних заходів з охорони їх психічного здоров'я.

Матеріал і методи. На засадах інформованої згоди з дотриманням принципів біоетики і деонтології протягом 2016-2019 років було обстежено 180 моряків далекого плавання: 110 членів командного складу торговельного флоту (КТФ), та 70 - пасажирського (КПФ). Дослідження включало використання клініко-психопатологічного і психодіагностичного методів.

Результати. В результаті дослідження встановлено, що представники командного складу морського торговельного і пасажирського флотів мають низку адиктивних феноменів хімічного і нехімічного походження, вираженість яких, в переважній більшості, $є$ на рівні «безпечного вживання» або «вживання зі шкідливими наслідками». «Вживання зі шкідливими наслідками», перш за все, встановлено тютюном і кавою/чаєм серед хімічних о6'єктів, а поведінкових - за тріадою об'єктів, пов'язаних з використанням інформаційних технологій - інтернетом, комп'ютерними іграми і телебаченням. У рамках одного діапазону вираженості схильності до адикції, за переважною кількістю об'єктів, більшою напруженістю АС (за усередненими показниками) характеризуються КТФ, порівняно з КПФ.

Висновки. Напруженість АС у командного складу морського торговельного і пасажирського флотів збільшується у міру прогресування психосоціального стресового навантаження, якого зазнають обстежені.

Виявлені закономірності повинні враховуватися при розробці специфічних заходів психотерапії і психопрофілактики для даного контингенту, що становить перспективу даного дослідження.

КлючОВІ СлОВА: моряки далекого плавання; командний склад торговельного морського флоту; командний склад пасажирського морського флоту; психосоціальний стрес; адиктивний статус.
\end{abstract}

Вступ. Специфіка морської професійної діяльності обумовлює необхідність тривалого перебування моряків на борту судна [1]. 3 цим фактором асоційована величезна кількість професійних шкідливостей, дія яких, за відсутності добре розвинених адаптаційних механізмів, швидко призводить до втрати працездатності й порушення стану здоров'я моряків [2].

Для суден торговельного морського флоту основу комплексу несприятливих зовнішніх механічних виробничих факторів складають шум, вібрація, широкочастотні електромагнітні випромінювання, а також наявність шкідливих речовин у повітрі приміщень тощо [3]. Психологічні чинники умов праці моряків детерміновані роботою в замкнутому просторі, сенсорною депривацією, підвищеною відповідальністю, жорсткою регламентацією вахтової циклограми діяльності, однотипним ландшафтом, обмеженими можливостями задоволення культурних потреб і спілкування, сексуальною фрустрацією, тривалим емоційним напруженням, незадоволеністю потреби в звичайних соціальних умовах для проживання, екстремальними факторами умов праці тощо [4].

У таких умовах одним із шляхів патологічної псевдокомпенсації афективного й психосоціаль- ного дискомфорту стає адиктивна поведінка моряків [5-9]. У дослідженні І. Gгарраsonni зі співав. (2019) наводяться дані щодо наявності у моряків далекого плавання високого ризику виникнення захворювань, пов'язаних із реалізацією шкідливих звичок та неправильним способом життя, серед яких дослідники відмічають насамперед куріння [10]. Вивчення особливостей споживання психоактивних речовин серед марокканських моряків-промисловців (2017) встановило поширеність куріння на рівні 58,5 \% вибірки, канабісу $36,2 \%$, надмірного вживання алкоголю - 36,5\% [11]. Дослідження адиктивного статусу французьких моряків, здійснене Е. Fort зі співавт. (2009), показало, що з 1928 обстежених 44 \% були курцями, 63 \% з яких мали клінічно окреслену тютюнову залежність, а більше 11 \% осіб споживали алкоголь щодня [12].

Сучасні жорсткі умови медичних оглядів у проміжних портах та вимоги судновласників не дозволяють більшості представників торговельного морського флоту обирати в якості об'єкта адикції переважну більшість психоактивних речовин, включаючи, звісно, алкоголь та інші наркотичні речовини, за винятком тютюну та кофеїну. В такому разі адиктивна амортизація стресового 
Огляди літератури, оригінальні дослідження, погляд на проблему, випадок з практики, короткі повідомлення навантаження може відбуватися за рахунок схильності до використання об'єктів нехімічного походження та розвитку так званих поведінкових адикцій, багато з яких є соціально прийнятними та не вважаються суспільством хворобливими [13]. Між тим, надмірна напруженість адиктивного статусу за будь-яким адиктивним об'єктом $\epsilon$ чинником ризику щодо формування психічних i поведінкових розладів унаслідок їх непомірного вживання, а також збільшення кількості ризикованих позаштатних ситуацій, що можуть призвести до аварійних ситуацій техногенного характеру.

Однак, не дивлячись на актуальність вищевказаного, на теперішній час роботи, які 6 були присвячені вивченню особливостей адиктивної поведінки моряків далекого плавання як в рейсовий, так і в міжрейсовий період, є поодинокими [11]. Це звужує можливості розробки і впровадження дієвих персоніфікованих заходів її профілактики та підтримки, корекції і збереження психічного здоров'я у цього специфічного контингенту.

Мета роботи - дослідити напруженість адиктивного статусу (AC) у представників командного складу морського торговельного і пасажирського флотів з різним рівнем психосоціального стресу (ПС), для визначення необхідності створення специфічних для даного контингенту системних заходів з охорони їх психічного здоров'я.

Матеріал і методи дослідження. Для досягнення поставленої мети на засадах інформованої згоди з дотриманням принципів біоетики і деонтології протягом 2016-2019 років було обстежено 180 командирів морського флоту України: 110 членів командного складу (капітани далекого пла-

вання, перші та другі помічники капітанів тощо) торговельного флоту (КТФ), та 70 - пасажирського (КПФ). Усі обстежені були чоловіками, громадянами України.

Усі респонденти були обстежені в період після повернення з рейсу на базі декількох медичних установ (КНП «Одеський обласний медичний центр психічного здоров'я" Одеської обласної ради, медичний центр «Академмарін» НУ ОМА, кафедра психіатрії, наркології та психології Одеського національного медичного університету, медичні центри «Крок до життя», «Віта» тощо), під час добровільного звернення за консультацією лікаряпсихіатра.

Дослідження включало використання клініко-психопатологічного і психодіагностичного методів. Після первинного структурованого інтерв'ю оцінювали рівень ПС, якого зазнавали респонденти (з використанням однойменної шкали Л. Рідера) [14]. Класичне клініко-психопатологічне обстеження пацієнтів з використанням діагностичних критеріїв MKX-10, було доповнено психометричним дослідженням 3 використанням тесту AUDIT [15] і батареї AUDIT-подібних тестів, розроблених колективом авторів під керівництвом I. В. Лінського [16] та тесту SPORT-UDIT [17].

Статистико-математичний аналіз включав формування описової статистики та аналіз розбіжностей з використанням непараметричних методів.

Результати й обговорення. Більшість представників обстежених обох груп була у віці 3650 років (53,6 \% КТФ і 68,5 \% КПФ); серед осі6 2535 років було 20,9 \% КТФ і 12,8 \% КПФ, старше 50 років - 25,4 \% КТФ і 18,6 \% КПФ (рис. 1).

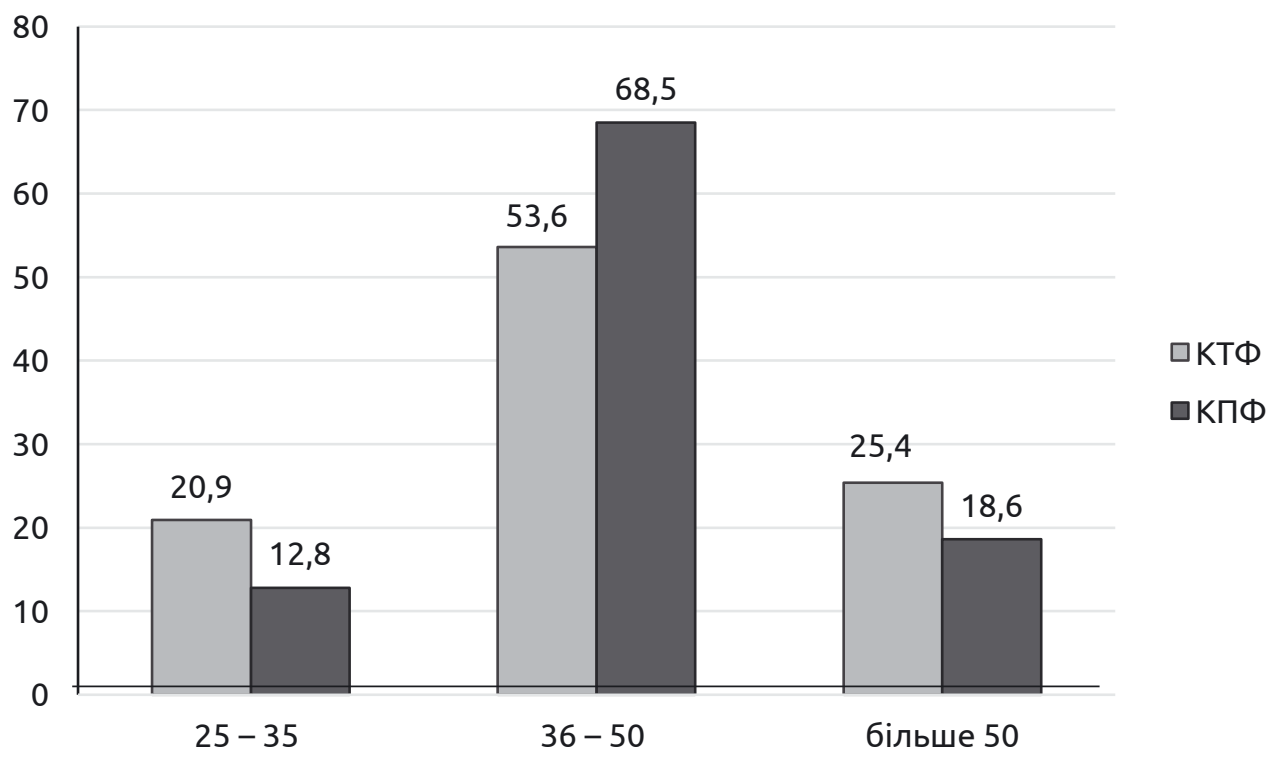

Рис. 1. Розподіл обстежених за віком. 
Огляди літератури, оригінальні дослідження, погляд на проблему, випадок з практики, короткі повідомлення

Більше половини чоловіків були одружені і $42,2 \%$ КПФ (p<0,05) (рис. 3). Помірний рівень (48,5 \% КТФ і 62,7 \% КПФ), інші - розлучені психосоціального стресового навантаження був (рис. 2).

Серед загальної кількості обстежених низький рівень ПС виявився притаманним 30,9 \% КТФ характерний для 52,7 \% КТФ й 44,3 \% КПФ $(p<0,05)$, тяжкий рівень ПС - для $16,4 \%$ КТФ і $12,8 \%$ КПФ $(p<0,01)$.

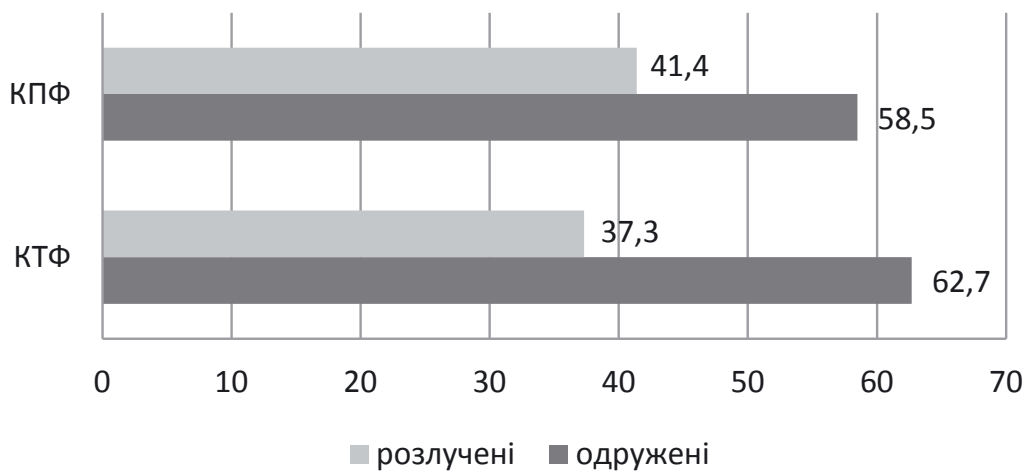

Рис. 2. Сімейний стан обстежених.

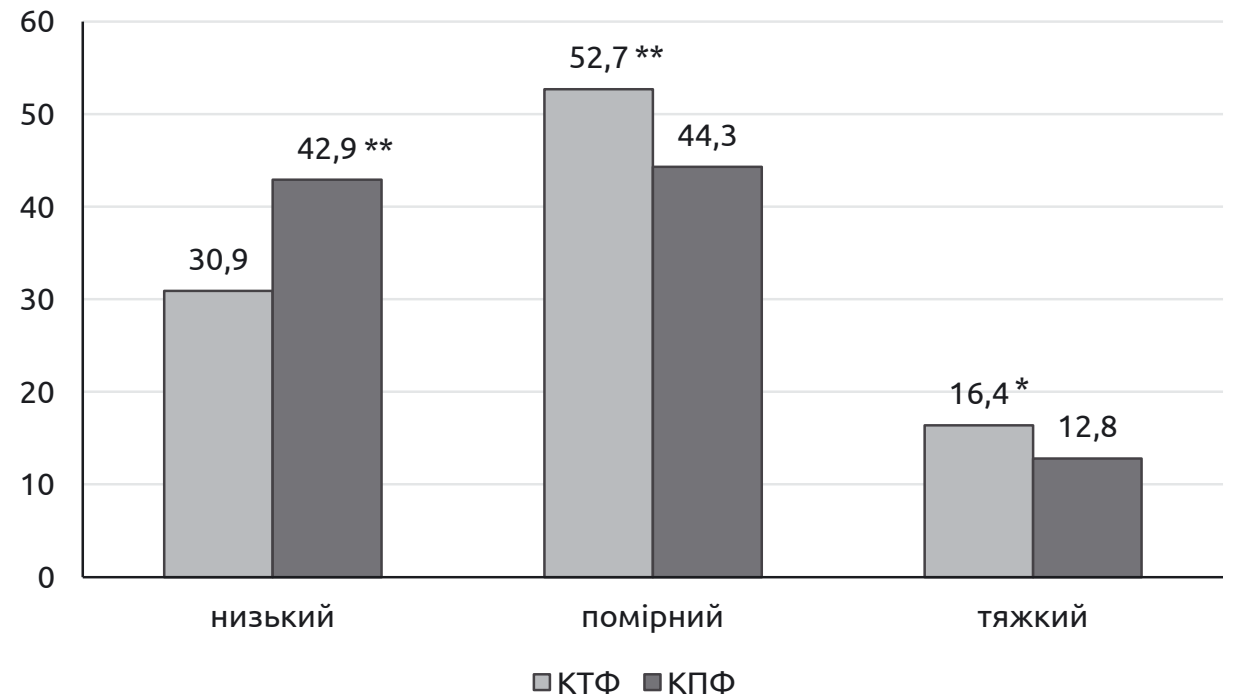

Примітка. Тут і далі: рівень статистичної значущості розбіжностей при порівнянні груп: * - p<0,01, **-p<0,05.

Рис. 3. Розподіл обстежених за рівнем психосоціального стресу, \%.

Оцінка загальної інтенсивності стресового навантаження (рис. 4) показала, що середні показники ПС у КТФ $(1,50 \pm 0,68$ балів) знаходилися в амплітуді помірних значень (1,00-1,99 балів), що свідчило про наднормовість стресу, тоді як КПФ менше відчували негативну дію ПС, про що свідчила кількість балів, що наближалася до верхньої межі низького рівня стресу (до 0,99 бала) - $(0,94 \pm 0,64)$ балів $(p<0,05)$. Така ж тенденція мала місце й при розподілі показників інтенсивності ПС у межах діапазонів низького, помірного і тяжкого стресу: стресовий тягар, що відчували обстежені, був більшим у КТФ, порівняно з КПФ (в межах низького ПС - $(0,77 \pm 0,07)$ у КТФ проти $(0,28 \pm 0,10)$ у КПФ, $\mathrm{p}<0,05$; помірного - $(1,54 \pm 0,28)$ у КТФ проти $(1,27 \pm 0,23)$ у КП $Ф$, $\mathrm{p}<0,05$; тяжкого $(2,73 \pm 0,18)$ у КТФ проти $(2,00 \pm 0,00)$ у КПФ, $\mathrm{p}<0,05)$.

Напруженість AC у командирів торговельного і пасажирського морського флотів виявилась підвищеною за низкою адиктивних об'єктів хімічного і нехімічного походження (рис. 5). 
Огляди літератури, оригінальні дослідження, погляд на проблему, випадок з практики, короткі повідомлення

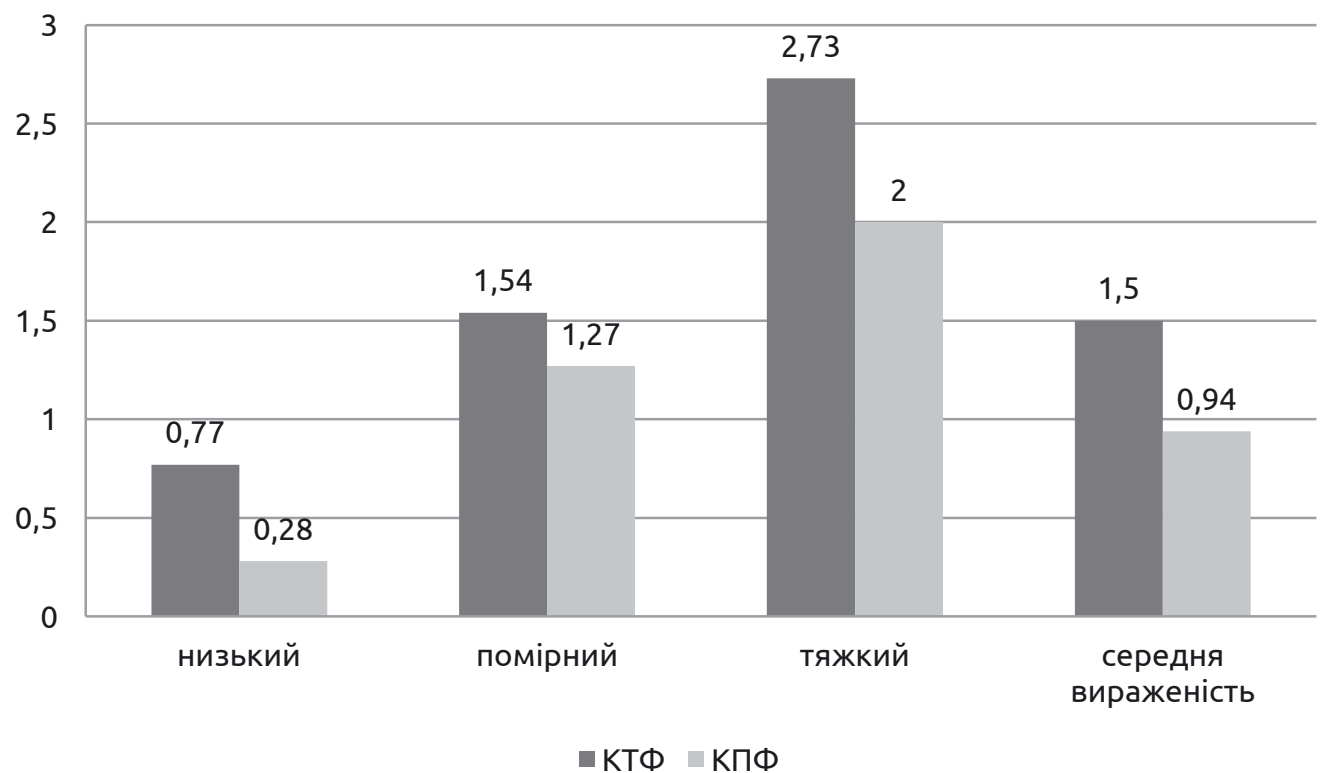

Рис. 4. Середні показники інтенсивності психосоціального стресу в обстежених, сер. бал.

Серед хімічних об'єктів виділено тютюн і каву/чай, серед поведінкових - роботу й об'єкти, пов'язані з використанням інформаційних технологій - інтернет, комп'ютерні ігри і телебачення. За вищеперерахованими потенційними адиктивними об'єктами напруженість АС була в межах "вживання зі шкідливими наслідками», за усіма іншими - показники АС свідчили про «безпечне вживання».

Однак зіставлення інтенсивності схильності до адиктивної реалізації за виділеними об'єктами між командирами торговельного і пасажирського флотів довело наявність значущих відмінностей. Так, за тютюном і кавою/чаєм усереднені показники напруженості АС у КТФ наближались до верхніх граничних значень діапазону «вживання зі шкідливими наслідками» $((12,2 \pm 11,77)$ балів за тютюном, $(13,47 \pm 7,01)$ балів за кавою/чаєм), тоді як у КПФ - до нижніх значень того ж діапазону $((7,11 \pm 4,60)$ балів за тютюном, $(10,63 \pm 4,71)$ балів за кавою/чаєм). Розбіжності між групами за обома об'єктами були статистично значущими на рівHi $p<0,05$.

Схожа ситуація спостерігалась і щодо об'єктів нехімічного походження - за роботою $((10,59 \pm$ $5,96)$ балів у КТФ і $(8,07 \pm 6,98)$ балів у КПФ, $p<0,05)$, комп'ютерними іграми $((7,64 \pm 4,67)$ балів у КТФ і $(6,46 \pm 5,39)$ у КПФ, $p<0,01)$ і телебаченням $((7,16 \pm$ $6,18)$ балів у КТФ і $(5,43 \pm 2,69)$ балів у КПФ, $\mathrm{p}<0,01)$. Схильність до використання Інтернету була підвищена у представників обох груп $((8,08 \pm 5,52)$ балів у КТФ і $(8,90 \pm 6,58)$ балів у КПФ), проте не мала статистично значущих розбіжностей між ними.
Треба зазначити, що за декількома об'єктами поведінкових адикцій, показники АС за якими в обох групах знаходились у межах «безпечного вживання», також були встановлені значущі відмінності: більша вираженість схильності до шопінгу у КТФ $((6,14 \pm 3,56)$ балів проти $(3,89 \pm 5,03)$ балів у КПФ, p<0,05), до азартних ігор $((5,44 \pm 5,24)$ балів у КТФ і $(6,27 \pm 8,25)$ балів КПФ, $><0,05)$ та читання $((4,47 \pm 2,76)$ балів у КТФ і $(6,90 \pm 4,88)$ балів у КПФ, $\mathrm{p}<0,05)$ - у КПФ.

Дослідження стану АС у осіб з різним рівнем ПС довело наявність значущих розбіжностей та дозволило стверджувати, що негативна динаміка напруженості АС зростає асоційовано зі збільшенням психосоціального стресового навантаження у всіх обстежених (табл. 1).

За алкоголем встановлена тенденція щодо більшого його вживання серед КПФ, порівняно $з$ КТФ, незалежно від рівня ПС: не дивлячись на те, що напруженість АС у осіб з низьким ПС була в межах «безпечного вживання», з помірним і тяжким - не виходила за межі «вживання зі шкідливими наслідками» в обох групах командирів (проте, демонструвала зростання у осіб з тяжким ПС, порівняно з помірним, $\mathrm{p}<0,05)$, усі показники КПФ були вищими, ніж у КТФ ( $p<0,01)$.

За АС стосовно тютюну загальний тренд до посилення схильності до адиктивної реалізації з потяжчанням стресу зберігався («безпечне вживання» - «вживання зі шкідливими наслідками»«небезпечне вживання», $p<0,05)$, проте тенденція їі розподілу між КТФ і КПФ була протилежною, тобто мала місце більш виражена напруженість 
Огляди літератури, оригінальні дослідження, погляд на проблему, випадок з практики, короткі повідомлення

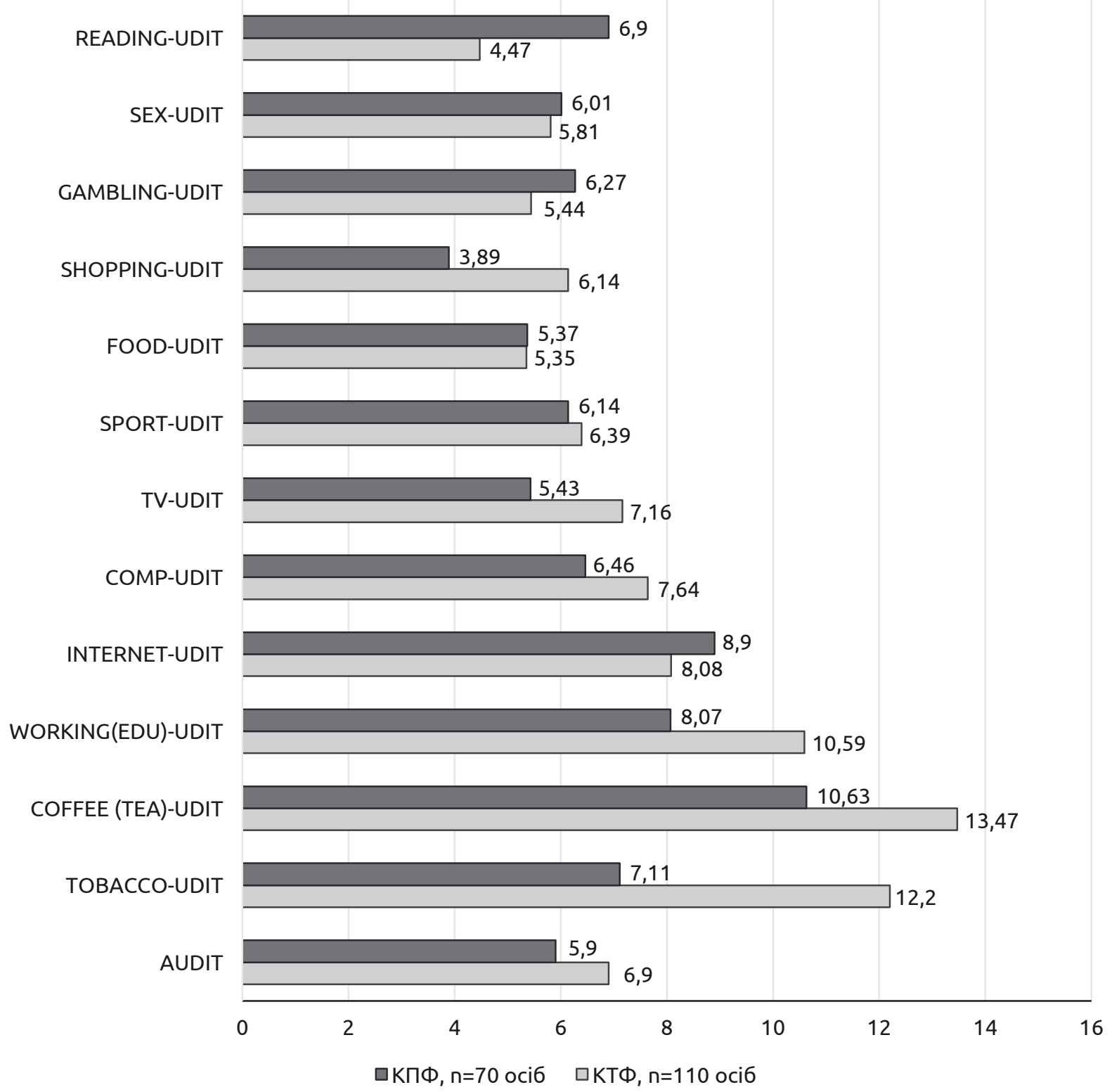

Рис. 5. Усереднені показники напруженості адиктивного статусу за різними адиктивними об'єктами у представників командного складу торговельного і пасажирського морського флотів, сер. бал.

Таблиця 1. Порівняння напруженості адиктивного статусу в КТФ і РТФ із різним рівнем психосоціального стресу, сер. бал $\pm m$

\begin{tabular}{|c|c|c|c|c|c|c|}
\hline \multirow{3}{*}{$\begin{array}{c}\text { Методичний інстру- } \\
\text { мент для визначення } \\
\text { напруженості АС за } \\
\text { адиктивним об'єктом }\end{array}$} & \multicolumn{6}{|c|}{ Рівень ПС } \\
\hline & \multicolumn{2}{|c|}{ низький } & \multicolumn{2}{|c|}{ помірний } & \multicolumn{2}{|c|}{ тяжкий } \\
\hline & КTФ & КПФ & КTФ & КПФ & КТФ & КПФ \\
\hline 1 & 2 & 3 & 4 & 5 & 6 & 7 \\
\hline AUDIT & $4,9 \pm 2,99$ & $5,42 \pm 3,60 *$ & $8,3 \pm 4,62$ & $9,88 \pm 5,83^{*}$ & $12,4 \pm 5,77$ & $13,54 \pm 6,15^{*}$ \\
\hline TOBACCO-UDIT & $5,53 \pm 6,21 *$ & $4,63 \pm 3,47$ & $12,90 \pm 9,41 *$ & $11,81 \pm 7,16$ & $18,28 \pm 10,07^{*}$ & $17,44 \pm 5,27$ \\
\hline COFFEE (TEA)-UDIT & $4,52 \pm 7,31$ & $6,20 \pm 1,10 *$ & $12,68 \pm 3,03$ ** & $10,48 \pm 3,55$ & $17,28 \pm 6,26$ & $17,22 \pm 5,87$ \\
\hline WORKING-UDIT & $7,12 \pm 5,68$ & $6,30 \pm 3,52$ & $11,03 \pm 6,49$ & $13,39 \pm 11,99$ & $11,94 \pm 4,14$ & $12,33 \pm 9,21$ \\
\hline INTERNET-UDIT & $6,29 \pm 6,18$ & $6,50 \pm 9,44$ & $8,07 \pm 5,31$ & $10,22 \pm 9,56 * *$ & $9,61 \pm 4,80$ & $13,74 \pm 11,85^{* *}$ \\
\hline COMP-UDIT & $5,88 \pm 4,59$ & $6,17 \pm 3,58$ & $9,69 \pm 3,75^{* *}$ & $7,55 \pm 5,78$ & $13,00 \pm 4,59$ & $12,00 \pm 9,00$ \\
\hline TV-UDIT & $5,15 \pm 10,19$ & $7,00 \pm 6,32 * *$ & $8,72 \pm 6,71$ & $11,77 \pm 10,48 * *$ & $8,78 \pm 8,76$ & $13,23 \pm 10,11^{* *}$ \\
\hline
\end{tabular}


Огляди літератури, оригінальні дослідження, погляд на проблему, випадок з практики, короткі повідомлення

Продовження табл. 1

\begin{tabular}{|l|c|c|c|c|c|c|}
\hline \multicolumn{1}{|c|}{1} & 2 & 3 & 4 & 5 & 6 & 7 \\
\hline SPORT-UDIT & $4,68 \pm 5,75$ & $5,60 \pm 6,86^{*}$ & $5,34 \pm 4,93$ & $6,00 \pm 8,84$ & $7,89 \pm 4,80$ & $8,44 \pm 10,01 *$ \\
\hline FOOD-UDIT & $5,97 \pm 3,29$ & $5,80 \pm 2,11$ & $10,57 \pm 2,31$ & $8,52 \pm 2,43$ & $12,61 \pm 1,61$ & $13,11 \pm 2,32 *$ \\
\hline SHOPPING-UDIT & $3,18 \pm 5,93$ & $3,77 \pm 3,98$ & $5,40 \pm 6,14$ & $5,52 \pm 3,36$ & $10,33 \pm 7,69$ & $10,57 \pm 7,89$ \\
\hline GAMBLING-UDIT & $3,24 \pm 9,03$ & $5,87 \pm 6,73$ & $5,44 \pm 9,74$ & $8,97 \pm 6,16 * *$ & $8,50 \pm 6,06$ & $13,00 \pm 7,50 * *$ \\
\hline SEX-UDIT & $4,09 \pm 8,26$ & $5,13 \pm 6,23$ & $6,48 \pm 10,56$ & $7,10 \pm 1,49$ & $8,11 \pm 13,43$ & $9,67 \pm 3,16 C$ \\
\hline READING-UDIT & $3,65 \pm 2,84$ & $4,97 \pm 2,92 * *$ & $4,72 \pm 2,77$ & $7,71 \pm 4,50 * *$ & $5,22 \pm 2,32$ & $10,56 \pm 8,20 * *$ \\
\hline
\end{tabular}

АС у КТФ, незалежно від вираженості ПС ( $<<0,01)$. Вживання кави/чаю підтвердило загальну тенденцію («безпечне вживання» - «вживання зі шкідливими наслідками» - «небезпечне вживання", $p<0,05)$, проте серед осіб з низьким ПС більше його вживання було притаманне КПФ $(p<0,01)$, з помірним ПС - КТФ ( $p<0,05)$, з тяжким ПС - статистично значущої різниці між групами не виявлено.

Динаміка напруженості АС за адиктивними нехімічними об'єктами продемонструвала таку ж закономірність, що й за хімічними адикціями (з різницею у вираженості показників серед осіб 3 тяжким стресом, які не доходили меж «небезпечного вживання», проте були більшими, ніж у осіб з помірним стресом, в межах діапазону «вживання зі шкідливими наслідками», зі значущістю розбіжностей від $p<0,01$ до $p<0,05)$.

Серед КПФ напруженість АС виявилась більшою за інтернетом (у осіб з помірним і тяжким ПС, $\mathrm{p}<0,05)$, телебаченням (у осіб з будь-яким рівнем ПС, $\mathrm{p}<0,05)$, спортом (у осіб з низьким і тяжким ПС, $\mathrm{p}<0,01)$, їжею (у осіб з тяжким ПС, $\mathrm{p}<0,01$ ), азартними іграми (у осіб з помірним і тяжким ПС, p<0,05) і читанням (у осіб з будь-яким рівнем ПС, p<0,05). Серед КТФ у осіб з помірним ПС була зафіксована більша схильність до адиктивної реалізації за комп'ютерними іграми $(p<0,05)$.

\section{ЛІТЕРАТУРА}

1. Рымина Т. Н. Особенности воздействия стресса на работников плавсостава в условиях работы на море / Т. Н. Рымина, Е. В. Пятырова // Здоровье. Медицинская экология. Наука. - 2014. - № 4 (58). - С. 103-105.

2. Мельникова И. П. Влияние производственных факторов на здоровье моряков / И. П. Мельникова // Гигиена и санитария. - 2007. - № 1. - С. 42-44.

3. Голованов А. Е. Влияние особенностей психики человека на процессы адаптации к укачиванию / А. Е. Голованов, Л. П. Макарова, Г. Г. Климентенок // Молодой ученый. - 2014. - № 4. - С. 357-361.

4. Стрелкова О. В. Психологические аспекты профессиональной деятельности моряков / О. В. Стрелкова //
Висновки. Представники командного складу морського торговельного і пасажирського флотів мають низку адиктивних феноменів хімічного і нехімічного походження, вираженість яких, в переважній більшості, $\epsilon$ на рівні «безпечного вживання» або «вживання зі шкідливими наслідками».

«Вживання зі шкідливими наслідками», перш за все, встановлено тютюном і кавою/чаєм серед хімічних об'єктів, а поведінкових - за тріадою о6'єктів, пов'язаних з використанням інформаційних технологій - Інтернетом, комп'ютерними іграми і телебаченням.

В рамках одного діапазону вираженості схильності до адикції, за переважною кількістю об'єктів більшою напруженістю АС (за усередненими показниками) характеризуються КТФ, порівняно з КПФ.

Напруженість АC у командного складу морського торговельного і пасажирського флотів збільшується по мірі прогресування психосоціального стресового навантаження, якого зазнають обстежені.

Перспективи подальших досліджень. Виявлені закономірності повинні враховуватися при розробці специфічних заходів психотерапії і психопрофілактики для даного контингенту, що становить перспективу даного дослідження.

Вестник Российского государственного университета им. И. Канта. - 2010. - Вып. 5. - С. 45-51.

5. Fort E. Psychoactive substances consumption in French fishermen and merchant seamen / E. Fort, A. Massardier-Pilonchéry, A. Bergeret // Int. Arch. Occup. Environ. Health. - 2010. - Vol. 83 (5). - P. 497-509. doi: 10.1007/ s00420-009-0473-y

6. Prevalence of drug use in French seamen / E. Fort, A. Massardier-Pilonchéry, F. Facy, A. Bergeret // Addictive Behaviors. - 2012. - Vol. 37, Issue 3. - P. 335-338.

7. Risk factors for fishermen's health and safety in Greece / E. Frantzeskou, A. N. Kastania, E. Riza [et al.] // Int. Marit. Health. - 2012. - Vol. 63 (3). - P. 155-161. 
Огляди літератури, оригінальні дослідження, поглядн

8. Jezewska $M$. Stress and fatigue at sea versus quality of life / M. Jezewska, R. Iversen // Int. Marit. Health. - 2012. - Vol. 63 (3). - P. 106-115.

9. Consumption of addictive substances in mariners / R. Pougnet, L. Pougnet, B. Loddé [et al.] // Int. Marit. Health. - 2014. - Vol. 65, Issue 4. - P. 199-204.

10. Survey on smoking habits among seafarers / I. Grappasonni, S. Scuri, F. Petrelli [et al.] // Acta. Bio. Med. - 2019. - Vol. 90, No. 4. - P. 489-497. Available from: https://www.mattioli1885journals.com/index.php/ actabiomedica/article/view/9001

11. Prevalence of consumption of addictive substances amongst Moroccan fishermen / O. Laraqui, S. Laraqui, N. Manar [et al.] // Int. Marit Health. - 2017. - Vol. 68 (1). P. 19-25. DOI: 10.5603/IMH.2017.0004

12. Fort $E$. Alcohol and nicotine dependence in French seafarers / E. Fort, A. Massardier-Pilonchery, A. Berget // International Maritime Health. - 2009. - Vol. 60 (1-2). P. 18-28.

13. Маркова М. В. Порушення здоров'я сім'ї та аддиктивна поведінка у жінок (механізми формування, взаємозв'язки, система психологічної корекції) / М. В. Маркова, М. В. Савіна // Fundamental and applied researches in

\section{REFERENCES}

1. Rymina, T.N., \& Pyatirova, Ye.V. (2014). Osobennosti vozdeystviya stressa na rabotnikov plavsostava v usloviyakh raboty na more [Features of the impact of stress on employees seafarers in terms of working in the sea]. Zdorovye. Meditsinskaya ekologiya. Nauka - Health. Medical Ecology. The Science, 4 (58), 103-105 [in Russian].

2. Melnikova, I.P. (2007). Vliyaniye proizvodstvennykh faktorov na zdorovye moryakov [Influence of production factors on the health of sailors]. Gigiyena i sanitariya - Hygiene and Sanitation, 1, $42-44$ [in Russian].

3. Golovanov, A.Ye., Makarova, L.P., \& Klimentenok, G.G. (2014). Vliyaniye osobennostey psikhiki cheloveka na protsessy adaptatsii k ukachivaniyu [Influence of the characteristics of the human psyche on the processes of adaptation to motion sickness]. Molodoy uchenyy - Young Scientist, 4, 357-361 [in Russian].

4. Strelkova, O.V. (2010). Psikhologicheskiye aspekty professionalnoy deyatelnosti moryakov [Psychological aspects of the professional activities of sailors]. Vestnik Rossiyskogo gosudarstvennogo universiteta im. I. Kanta - Bulletin of the Russian State University by I. Kant, 5, 45-51 [in Russian].

5. Fort, E., Massardier-Pilonchéry, A., \& Bergeret, A. (2010). Psychoactive substances consumption in French fishermen and merchant seamen. Int. Arch. Occup. Environ. Health, 83 (5), 497-509. doi: 10.1007/s00420-009-0473-y

6. Fort, E., Massardier-Pilonchéry, A., Facy, F., \& Bergeret, A. (2012). Prevalence of drug use in French seamen. Addictive Behaviors, 37, 3, 335-338.

7. Frantzeskou, E., Kastania, A.N., Riza, E., Jensen, O.C., \& Linos, A. (2012). Risk factors for fishermen's health and safety in Greece. Int. Marit. Health, 63 (3), 155-161. облему, випадок з практики, короткі повідомлення practice of leading scientific schools. - 2018. - Vol. 25 (1). P. 89-108.

14. Спосіб діагностики клінічної специфіки і прогнозу перебігу алкогольної залежності у осіб з різним психотравматичним досвідом і рівнем психосоціального стресу / К. Д. Гапонов, І. К. Сосін, О. Ю. Гончарова, М. В. Маркова // Інформаційний лист МОЗ України № 249-2018. - $4 \mathrm{C}$.

15. AUDIT. Alcohol Use Disorders Identification Test / Th. F. Babor, J. C. Higgins-Biddle, J. B. Saunders, M. G. Monteiro // WHO/MSD/MSB/01.6a Original: English Distribution: General. - 2001. -28 p.

16. Метод комплексной оценки аддиктивного статуса индивида и популяции с помощью системы AUDITподобных тестов / И. В. Линский, А. И. Минко, А. Ф. Артемчук [и др.] // Вісник психіатрії та психофармакотерапiї. - 2009. - № 2 (16). - С. 56-70.

17. Маркова М. В. Тест для виявлення розладів, пов'язаних з захопленістю спортом (фітнесом) SPORTUDIT (версія «самозвіт») для непрофесіоналів / М. В. Маркова, М. В. Савіна. Свідоцтво про реєстрацію авторського права на твір № 70682 від 24.02.2017 р.
8. Jezewska, M., \& Iversen, R. (2012). Stress and fatigue at sea versus quality of life. Int. Marit. Health, 63 (3), 106-115.

9. Pougnet, R., Pougnet, L., Loddé, B., Canals, L., Bell, S., Lucas, D., \& Dewitte, J.-D. (2014). Consumption of addictive substances in mariners. Int. Marit. Health, 65, 4, 199-204.

10. Grappasonni, I., Scuri, S., Petrelli, F., Nguyen, C.T.T., Sibilio, F., Di Canio, M., ..., \& Amenta, F. (2019). Survey on smoking habits among seafarers. Acta Bio. Med., 90, 4, 48949. Retrieved from: https://www.mattioli1885journals. com/index.php/actabiomedica/article/view/9001.

11. Laraqui, O., Laraqui, S., Manar, N., Ghailan, T., Deschamps, F., \& Laraqui, C.H. (2017). Prevalence of consumption of addictive substances amongst Moroccan fishermen. Int. Marit. Health, 68 (1), 19-25. doi: 10.5603/ IMH.2017.0004

12. Fort, E., Massardier-Pilonchery, A., \& Berget, A. (2019). A. Alcohol and nicotine dependence in French seafarers. International Maritime Health, 60 (1-2), 18-28.

13. Markova, M., \& Savina, M. (2018). Porushennia zdorovia simi ta addyktyvna povedinka u zhinok (mekhanizmy formuvannia, vzaiemozviazky, systema psykholohichnoi korektsii) [Family health and addictive behavior in women (mechanisms of development, interrelations, system of psychological correction and psychoprophylactic support)]. Fundamental and Applied Researches in Practice of Leading Scientific Schools, 25 (1), 89-108 [in Ukrainian].

14. Haponov, K.D., Sosin, I.K., Honcharova, O.Yu., \& Markova, M.V. (2018). Sposib diahnostyky klinichnoi spetsyfiky i prohnozu perebihu alkoholnoi zalezhnosti u osib z riznym psykhotravmatychnym dosvidom i rivnem psy- 
Огляди літератури, оригінальні дослідження, погляд на проблему, випадок з практики, короткі повідомлення khosotsialnoho stresu [A method of diagnosis of clinical specificity and prognosis of alcohol dependence in persons with different psychotraumatic experience and level of psychosocial stress]. Informatsiynyi lyst MOZ Ukrainy Information Sheet of the Ministry of Health of Ukraine, No. 249-2018, 4 p. [in Ukrainian].

15. Babor, Th.F., Higgins-Biddle, J.C., Saunders, J.B., \& Monteiro, M.G. (2001). AUDIT. Alcohol Use Disorders Identification Test. WHO/MSD/MSB/01.6a Original: English Distribution: General.

16. Linskiy, I.V., Minko A.I., Artemchuk, A.F., Grinevich, Ye.G., Markova, M.V., Musiyenko, G.A., ..., \& Vyglazova, O.V. (2009). Metod kompleksnoy otsenki addiktivnogo statusa individa i populyatsii s pomoshchyu sistemy AUDIT-

podobnykh testov [Method for comprehensive assessment of the additive individual status and population using the audit-like test system]. Visnyk psykhiatrii ta psykhofarmakoterapii - Bulletin of Psychiatry and Psychopharmacotherapy, 2 (16), 56-70 [in Russian].

17. Markova, M.V., \& Savina, M.V. (2017). Test dlia vyiavlennia rozladiv, poviazanykh z zakhoplenistiu sportom (fitnesom) SPORT-UDIT (versiia "samozvit") dlia neprofesionaliv [Test for identifying sports related fitness (fitness) disorders SPORT-UDIT (self-report version) for non-professionals]. Svidotstvo pro reiestratsiiu avtorskoho prava na tvir № 70682 vid 24.02.2017 r. - Certificate of Registration of Copyright for the Work No. 70682 of 24.02.2017 [in Ukrainian].

\title{
АНАЛИЗ АДДИКТИВНОГО ФЕНОМЕНА У ПРЕДСТАВИТЕЛЕЙ КОМАНДНОГО СОСТАВА МОРСКИХ ТОРГОВОГО И ПАССАЖИРСКОГО ФЛОТОВ
}

\author{
ОК. А. Косенко ${ }^{1,2}$, К. Д. Гапонов ${ }^{2}$ \\ ${ }^{1}$ КНП «Одесский областной медицинский центр психического здоровья» Одесского областного совета \\ ${ }^{2}$ Харьковская медицинская академия последипломного образования
}

Цель работы - исследовать напряженность аддиктивного статуса (АС) у представителей командного состава морского торгового и пассажирского флотов с различным уровнем психосоциального стресса (ПС), для определения необходимости создания специфических для данного контингента системных мер по охране их психического здоровья.

Материал и методы. На основе информированного согласия с соблюдением принципов биоэтики и деонтологии в течение 2016-2019 годов было обследовано 180 моряков дальнего плавания: 110 членов командного состава торгового флота (КТФ) и 70 - пассажирского (КПФ). Исследование включало использование клинико-психопатологического и психодиагностического методов.

Результаты. В результате исследования установлено, что представители командного состава морского торгового и пассажирского флотов имеют ряд аддиктивных феноменов химического и нехимического происхождения, выраженность которых, в подавляющем большинстве, находится на уровне «безопасного употребления» или "употребления с вредными последствиями». "Употребление с вредными последствиями», прежде всего, установлено табаком и кофе/чаем среди химических объектов, а поведенческих - с триадой объектов, связанных с использованием информационных технологий - интернета, компьютерных игр и телевидениея. В рамках одного диапазона выраженности склонности к аддикции, за подавляющим количеством объектов большей напряженностью АС (по усредненным показателям) характеризуются КТФ, по сравнению с КПФ.

Выводы. Напряженность АС у командного состава морского торгового и пассажирского флотов увеличивается по мере прогрессирования психосоциальной стрессовой нагрузки, которую испытывают обследованные.

Выявленные закономерности должны учитываться при разработке специфических мер психотерапии и психопрофилактики для данного контингента, что составляет перспективу данного исследования.

КЛЮЧЕВЫЕ СЛОВА: моряки дальнего плавания; командный состав торгового морского флота; командный состав пассажирского морского флота; психосоциальный стресс; аддиктивного статус.

\section{ANALYSIS OF ADDICTIVE PHENOMENA IN THE REPRESENTATIVES OF THE COMMAND STAFF OF THE MERCHANT AND PASSENGER-CARRYING FLEETS}

\author{
@K. A. Kosenko ${ }^{1,2}$, K. D. Gaponov ${ }^{2}$ \\ 1 "Odesa Regional Medical Center of Mental Health" of the Odesa Regional Council \\ ${ }^{2}$ Kharkiv Medical Academy of Postgraduate Education
}

SUMMARY. The aim - to investigate the intensity of addictive status in the representatives of the command staff of the merchant and passenger-carrying fleets with different levels of psychosocial stress, to determine the need to create system-specific measures for the protection of their mental health.

Material and Methods. Based on informed consent in compliance with the principles of bioethics and deontology, 180 sailors of long-distance voyages were surveyed in 2016-2019: 110 members of command staff of the merchant fleet, and 70 members of the passenger-carrying fleet. The study involved the use of clinical psychopathological and psychodiagnostic methods. 
Огляди літератури, оригінальні дослідження, погляд на проблему, випадок з практики, короткі повідомлення

Results. The results of the study have established that representatives of the command staff of the merchant and passenger-carrying fleets have a number of addictive phenomena of chemical and non-chemical origin, the severity of which, in the vast majority, are at the level of "safe consumption" or "harmful consumption". "Harmful consumption" is primarily established by tobacco and coffee/tea among chemical objects, and behavioral - by a triad of information technology related objects - the Internet, computer games and television. Within the same range of severity of addiction, with the overwhelming number of objects higher intensity of addictive status (by averaged indicators) are characterized for the members of command staff of the merchant fleet, compared to the members of the passenger-carrying fleet.

Conclusions. The intensity of addictive status in the command staff of the merchant and passenger-carrying fleets increases as the psychosocial stress experienced by the surveyed progresses.

The identified patterns should be taken into account when developing specific measures of psychotherapy and psychoprophylaxis for this contingent, which is the perspective of this study.

KEY WORDS: sailors of long-distance voyages; command staff of the merchant fleet; command staff of the passenger-carrying fleet; psychosocial stress; addictive status.

Отримано 02.02.2020 